\title{
Corrosion Inhibition and Adsorption Behavior of Cationic Surfactant Derived from Amine on Carbon Steel in Hydrochloric Acid Solutions
}

\author{
A. S FOUDA ${ }^{1}$, S. M. WANEES ${ }^{2}$ and A. MODREK ${ }^{3}$ \\ ${ }^{1}$ Department of Chemistry, Faculty of Science, El-Mansoura University, \\ El-Mansoura-35516, Egypt \\ ${ }^{2}$ Department of Chemistry, Faculty of Science, Zagazig University, Zagazig, Egypt \\ ${ }^{3}$ Chemist, United Gas Derivatives Company UGDC, Egypt \\ asfouda@mans.edu.eg
}

Received 13 April 2015 / Accepted 18 May 2015

\begin{abstract}
Inhibitive action of stearamidopropyl dimethylamine (SAPDA) which considered as cationic surfactant against the corrosion of carbon steel in a $0.5 \mathrm{M} \mathrm{HCl}$ solutions was investigated using electrochemical impedance spectroscopy (EIS), linear polarization resistance (LPR) and potentiodynamic polarization techniques. This investigated compound was found to act as effective corrosion inhibitor for the tested system. The polarization data indicated that this surfactant acts as mixed type inhibitor. The inhibition efficiency increased with increasing cationic surfactant concentration and decreased with raising the temperature. The adsorption of the cationic surfactant on the carbon steel surface followed the Langmuir adsorption isotherm model.
\end{abstract}

Keywords: Carbon steel, Acid corrosion, Cationic surfactant, EIS, LPR

\section{Introduction}

The carbon steel is used as essential part in the manufacturing and installations used in the petroleum and other industries. The use of inhibitors is one of the most practical methods for protection against metallic corrosion, especially in acidic media. The action of inhibition of the steel corrosion in acidic media by various organic compounds has been widely studied ${ }^{1-5}$. Hydrochloric and sulfuric acids are often used in the pickling of the steel and ferrous alloys. Inhibitors find applications in pickling, cleaning and acid descaling processes. In general, organic compounds such as amines, acetylenic alcohols, heterocyclic compounds etc., have found used as inhibitors in industrial applications ${ }^{6-16}$.

The aim of this paper is to study the inhibition action of stearamidopropyl dimethylamine as cationic surfactant using some electrochemical techniques. Also to investigate the effect of temperature on the inhibition efficiency 


\section{Experimental}

Materials used for the study were carbon steel sheet of composition shown in Table 1. The aggressive solutions of $0.5 \mathrm{M} \mathrm{HCl}$ were prepared by dilution of analytical grade AR grade $\mathrm{HCl}$ with bi-distilled water. Appropriate concentrations of acid with and without adding inhibitor were prepared using bi-distilled water.

Table 1. Chemical composition of carbon steel used in this study

\begin{tabular}{cccccccc}
\hline Element & $\mathrm{Fe}$ & $\mathrm{C}$ & $\mathrm{Mn}$ & $\mathrm{P}$ & $\mathrm{Si}$ & $\mathrm{Cr}$ & $\mathrm{Co}$ \\
\hline \multirow{2}{*}{ Weight \% } & \multirow{2}{*}{ Balance } & $0.150-$ & $0.350-$ & $0.016-$ & $0.003-$ & $0.018-$ & $0.145-$ \\
& & 0.200 & 0.600 & 0.024 & 0.098 & 0.026 & 0.245 \\
\hline
\end{tabular}

The cationic surfactant, stearamidopropyl dimethylamine (SAPDA) was supplied from Shanghi Dejun chemical technology Co., Ltd. Molecular structure of the investigated cationic surfactant as shown in Figure 1 and some other physical properties are presented in Table 2.

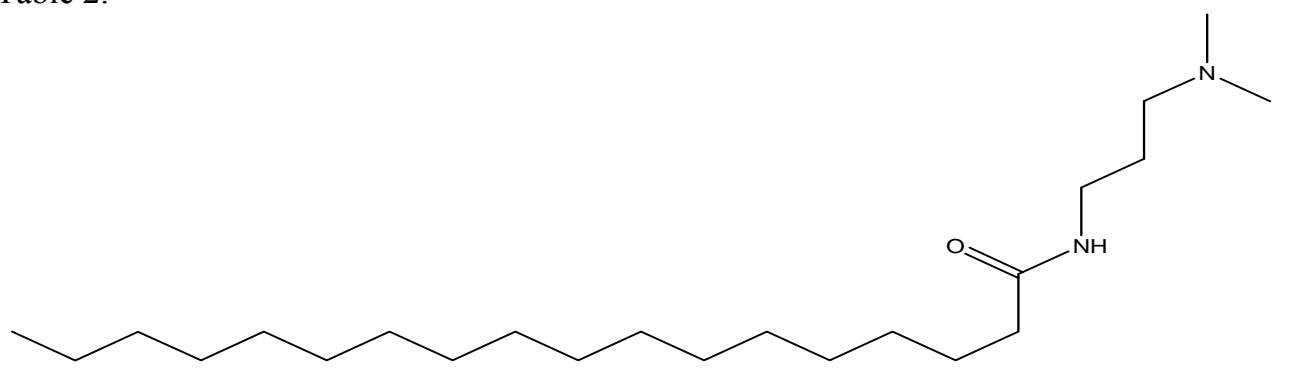

Figure 1. Stearamidopropyl dimethylamine (SAPDA)

Table 2. Chemical structure of stearamidopropyl dimethylamine (SAPDA) and some other physical properties

\begin{tabular}{cccccc}
\hline Type & Chemical name & $\begin{array}{c}\text { Mol.Wt, } \\
\mathrm{g} / \mathrm{mol}\end{array}$ & Appearance & $\mathrm{pH}$ & $\begin{array}{c}\text { Content, } \\
\%\end{array}$ \\
\hline $\begin{array}{c}\text { Cationic } \\
\text { surfactant }\end{array}$ & $\begin{array}{c}\text { Stearamidopropyl } \\
\text { dimethylamine } \mathrm{C}_{23} \mathrm{H}_{48} \mathrm{~N}_{2} \mathrm{O}\end{array}$ & 368.64 & $\begin{array}{c}\text { Light } \\
\text { yellow } \\
\text { paste }\end{array}$ & 4.0-8.0 & $70 \pm 2$ \\
\hline
\end{tabular}

All electrochemical experiments were carried out using Gamry PCI300/4 Potentiostat/ Galvanostat/Zra analyzer, DC105 corrosion software, EIS300 electrochemical impedance spectroscopy software, EFM140 electrochemical frequency modulation software and Echem Analyst 5.21 for results plotting, graphing, data fitting and calculating. The corrosion cell used had three electrodes. The reference electrode was a saturated calomel electrode (SCE). A platinum electrode was used as auxiliary electrode. The working electrode was carbon steel. All potentials given in this study were referred to this reference electrode. The working electrode was in the form of a square cut from carbon steel embedded in epoxy resin of polytetrafluoroethylene (PTFE) so that the flat surface was the only surface in the electrode and was immersed in the test solution for $30 \mathrm{~min}$, to establish a steady state open circuit potential (Eocp). After measuring the Eocp, the electrochemical measurements were performed.

\section{Electrochemical impedance spectroscopy (EIS) measurements}

All electrochemical tests have been performed in aerated solutions at 293K. The EIS experiments were conducted in the frequency range from $100 \mathrm{kHz}$ to $0.1 \mathrm{~Hz}$ at open circuit 
potential by applying $10 \mathrm{mV}$ ac voltage peak-to-peak. Nyquist plots were made from these experiments and the best semicircle can be fitted through the data points in the Nyquist plot using a non-linear least square fit so as to give the intersections with the $\mathrm{X}$-axis.

\section{Linear polarization resistance (LPR) measurements}

Linear polarization resistance measurements were carried out by polarizing the specimen from +20 to $-20 \mathrm{mV}$ with respect to $E_{\text {corr }}$, at a scanning rate of $0.1 \mathrm{mV} / \mathrm{s}$. All the tests were carried out at $293 \mathrm{~K}$ and after $30 \mathrm{~min}$ from the addition of the surfactant.

\section{Potentiodynamic polarization measurements}

The electrochemical behavior of carbon steel sample in the inhibited and uninhibited solution was studied by recording cathodic and anodic potentiodynamic polarization curves. Measurements were performed in the $0.5 \mathrm{M} \mathrm{HCl}$ solutions containing different concentrations of the SAPDA by changing the electrode potential automatically from -500 to $+1500 \mathrm{mV}$ versus corrosion potential at a scan rate of $1 \mathrm{mV} \mathrm{s}^{-1}$. The linear Tafel segments of anodic and cathodic curves were extrapolated to corrosion potential to obtain corrosion current densities $\left(i_{\text {corr }}\right)$.

\section{Results and Discussion}

\section{Potentiodynamic polarization technique}

The polarization curves of carbon steel in $0.5 \mathrm{M} \mathrm{HCl}$ without and with different concentrations of SAPDA. With the increase of SAPDA concentrations, both anodic and cathodic currents were inhibited. The numerical values of the variations in corrosion current density $\left(i_{\text {corr }}\right)$, corrosion potential $\left(E_{\text {corr }}\right)$, anodic Tafel slope $\left(\beta_{a}\right)$, cathodic Tafel slope $\left(\beta_{c}\right)$ and inhibition efficiency (IE \%) with the concentrations of SAPDA at all studied temperature are depicted in Table 3 . The $I E \%$ is calculated from the following equation $a^{17}$ :

$$
I E \%=\frac{i_{\text {corr }(\text { uninh })}-i_{\text {corr }(\text { inh })}}{i_{\text {corr }(\text { uninh })}} X 100
$$

Where $i_{\text {corr(uninh) }}$ and $i_{\text {corr(inh) }}$ are the corrosion current densities in the absence and presence of inhibitor, respectively.

Table 3. Data from potentiodynamic polarization of carbon steel in $0.5 \mathrm{M} \mathrm{HCl}$ containing various concentrations of SAPDA at $293 \mathrm{~K}$

\begin{tabular}{cccccccc}
\hline $\begin{array}{c}\mathrm{C} \\
\mathrm{ppm}\end{array}$ & $\begin{array}{c}\beta_{\mathrm{a}} \\
\mathrm{mV} \mathrm{dec}\end{array}$ & $\begin{array}{c}\beta_{\mathrm{c}} \\
\mathrm{mV} \mathrm{dec}^{-1}\end{array}$ & $\begin{array}{c}i_{\text {corr }} \\
\mu \mathrm{A} \mathrm{cm}^{-2}\end{array}$ & $\begin{array}{c}-E_{\text {corr }} \\
\mathrm{mV} \text { vs. SCE }\end{array}$ & $\begin{array}{c}C R \\
\mathrm{mpy}\end{array}$ & $\% I E$ & $\Theta$ \\
\hline 0.0 & 94 & 107 & 125.0 & 474 & 28.13 & -- & -- \\
10 & 118 & 208 & 49.8 & 514 & 19.04 & 60.2 & 0.602 \\
50 & 95 & 184 & 37.2 & 511 & 21.00 & 70.2 & 0.702 \\
100 & 90 & 172 & 26.4 & 499 & 14.88 & 78.9 & 0.789 \\
150 & 91 & 155 & 14.4 & 501 & 8.10 & 88.5 & 0.885 \\
200 & 77 & 180 & 12.6 & 463 & 7.13 & 89.9 & 0.899 \\
250 & 82 & 151 & 8.5 & 487 & 4.80 & 93.2 & 0.932 \\
\hline
\end{tabular}

The data of Table 3 showed that the $I E \%$ was increased with an increase in the concentration of SAPDA. It was found that the addition of SAPDA suppressed both anodic and cathodic reactions due to its adsorption on the carbon steel surface blocking the active sites. The results showed that the increase in inhibitor concentration leads to decrease the corrosion current density $\left(i_{\text {corr }}\right)$ as shown for Table $3 \&$ Figure 2 but the Tafel slopes $\left(\beta_{a}, \beta_{c}\right)$, 
are approximately constant indicating that the retardation of the two reactions (cathodic hydrogen reduction and anodic metal dissolution) were affected without changing the corrosion mechanism. It is reported that if the shift in corrosion potential exceeds $\pm 85 \mathrm{mV}$ with respect to corrosion potential of the uninhibited solution, the inhibitor acts as either anodic or cathodic type. In the present case the maximum displacement in $E_{\text {corr }}$ was found to be within $+40 \mathrm{mV}$, which indicates that SAPDA acts as mixed type of inhibitor ${ }^{18}$.

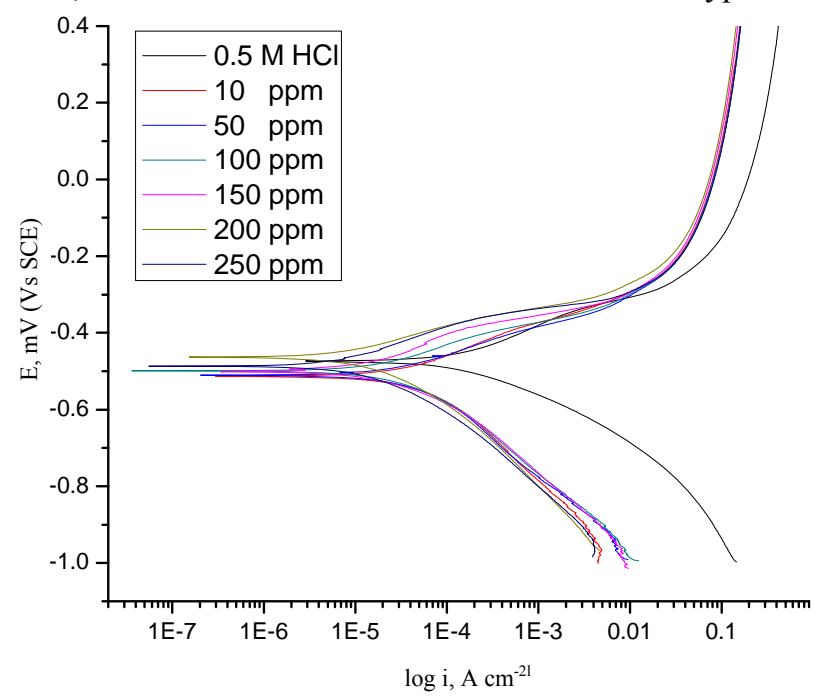

Figure 2. Potentiodynamic polarization curves for corrosion of carbon steel in $0.5 \mathrm{M} \mathrm{HCl}$ in the absence and presence of different concentrations of SAPDA at 293K

\section{Electrochemical impedance spectroscopy (EIS) measurements}

The effect of SAPDA concentration on the impedance behavior of carbon steel in $0.5 \mathrm{M} \mathrm{HCl}$ solutions at $293 \mathrm{~K}$ is presented in Figure 3. The curves shows a similar type of Nyquist plots. The existence of single semi-circle showed the single charge transfer process during dissolution which is unaffected by the presence of inhibitor molecules. Deviations from perfect circular shape are often referred to the frequency dispersion of interfacial impedance which arises due to surface roughness, impurities, dislocations, grain boundaries, adsorption of inhibitors, and formation of porous layers and in homogenates of the electrode surface ${ }^{19}$. Inspections of the data reveal that each impedance diagram consists of a large capacitive loop with one capacitive time constant in the Bode-phase plots Figure 4. It can be concluded from Figure 4 that the impedance response of carbon steel significantly changed after the addition of SAPDA in the corrosive solution. This can be attributed to an increase in substrate impedance with the increase in inhibitor concentrations.

The electrical equivalent circuit model is shown in Figure 5. It is used to analyze the obtained impedance data. The model consists of the solution resistance $\left(R_{s}\right)$, the charge-transfer resistance of the interfacial corrosion reaction $\left(R_{c t}\right)$ and the double layer capacitance $\left(C_{d l}\right)$. Excellent fit with this model was obtained with our experimental data. EIS data Table 4 show that the $R_{c t}$ values increases and the $C_{d l}$ values decreases with increasing the inhibitor concentrations. This is due to the gradual replacement of water molecules by the adsorption of the inhibitor molecules on the metal surface, decreasing the extent of dissolution reaction. The high $\left(R_{c t}\right)$ values, are generally associated with slower corroding system ${ }^{20,21}$. 
The double layer capacitance $\left(C_{d l}\right)$ and inhibition efficiency $(I E \%)$ are calculated from the following equations ${ }^{22}$ :

$$
\begin{aligned}
C_{d l} & =\frac{1}{2 \pi R_{c t} F_{\text {max }}} \\
I E \% & =\frac{R^{c t}-R_{c t}^{o}}{R_{c t}} X 100
\end{aligned}
$$

Where $F_{\max }$ is the frequency at apex on Nyquist plot, $R_{c t}^{\circ}$ and $R_{c t}$ are the charge transfer resistance values at the absence and presence of inhibitor, respectively. As seen from Table 4.
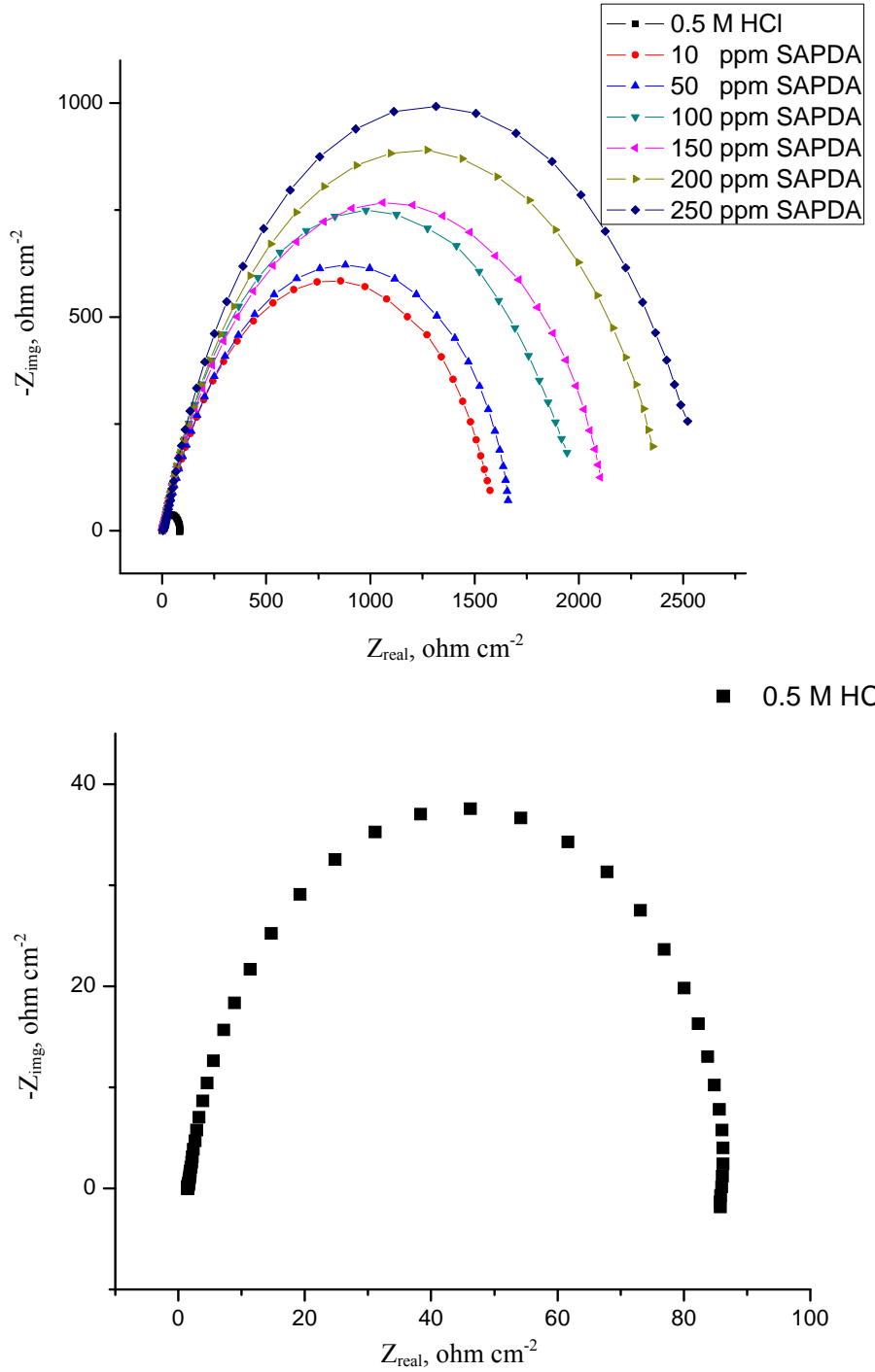

Figure 3. Nyquist plots for carbon steel in $0.5 \mathrm{M} \mathrm{HCl}(a)$ in the absence and presence of different concentrations of SAPDA $(b)$ at $293 \mathrm{~K}$ 


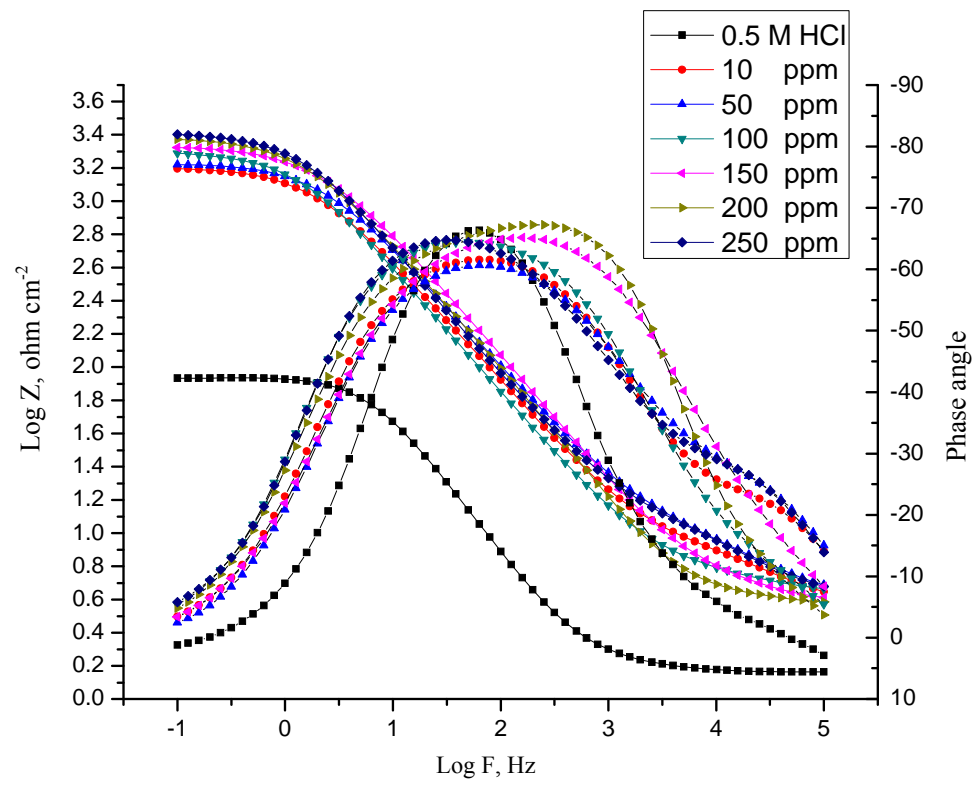

Figure 4. Bode plot of carbon steel recorded in $0.5 \mathrm{M} \mathrm{HCl}$ electrolyte in the absence and the presence of different concentrations from SAPDA at 293K.

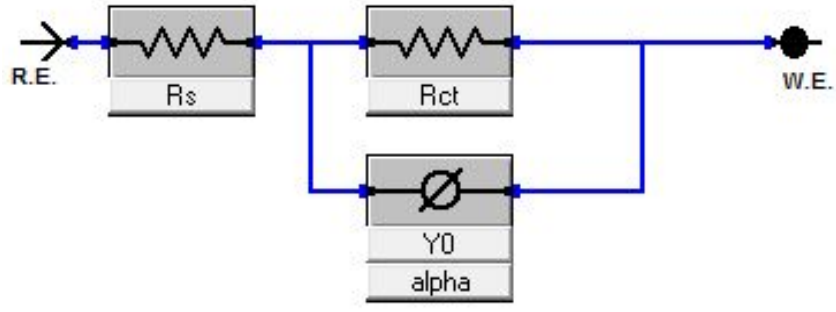

Figure 5. Electrical equivalent circuit model used to fit the results of impedance

Table 4. The data were obtained by modeling EIS spectra recorded in $0.5 \mathrm{M} \mathrm{HCl}$ solution with different concentrations of SAPDA at $293 \mathrm{~K}$

\begin{tabular}{cccccccc}
\hline $\begin{array}{c}\text { Conc., } \\
\mathrm{ppm}\end{array}$ & $\begin{array}{c}R_{S} \\
\Omega \mathrm{cm}^{-2}\end{array}$ & $\begin{array}{c}Y_{o} \times 10^{5} \\
\Omega^{-1} \mathrm{~s}^{\mathrm{n}} \mathrm{cm}^{-2}\end{array}$ & $n$ & $\begin{array}{c}R_{c t} \\
\mathrm{~cm}^{-2}\end{array}$ & $\begin{array}{c}C_{d l} \\
\mu \mathrm{F} \mathrm{cm}\end{array}$ & $\% I E$ & $\Theta$ \\
\hline 0.0 & 1.493 & 42.10 & 0.8928 & 87 & 283.05 & -- & -- \\
10 & 4.930 & 10.40 & 0.7285 & 1741 & 55.16 & 95.0 & 0.950 \\
50 & 5.206 & 9.28 & 0.7125 & 1870 & 45.78 & 95.4 & 0.954 \\
100 & 4.864 & 9.48 & 0.7731 & 2101 & 59.07 & 95.9 & 0.959 \\
150 & 4.038 & 5.84 & 0.7706 & 2201 & 52.96 & 96.1 & 0.961 \\
200 & 3.708 & 6.00 & 0.8018 & 2423 & 37.27 & 96.4 & 0.964 \\
250 & 5.389 & 8.70 & 0.7343 & 2916 & 31.69 & 97.0 & 0.970 \\
\hline
\end{tabular}

The decrease in the $C_{d l}$ can result from the decrease of the local dielectric constant and/or from the increase of thickness of the electrical double layer suggested that the inhibitor molecules function by adsorption at the metal/solution interface ${ }^{20,21}$. 


\section{Linear polarization resistance (LPR) measurements}

The linear polarization resistance curves of carbon steel with and without SAPDA addition has been illustrated in Figure 6 and the corrosion parameters are given in Table 5. The corrosion current density $\left(i_{\text {corr }}\right)$ values without inhibitor is higher than those observed with inhibitor addition and gradually decrease as the concentration of SAPDA increase and the corrosion rates had the same trend, $I E$ was evaluated as follows ${ }^{23}$ :

$$
I E \%=\frac{R_{p}-R_{p}^{o}}{R_{p}} X 100
$$

Where $R_{P}^{\circ}$ and $R_{P}$ are the polarization resistance values in the absence and presence of inhibitor, respectively.

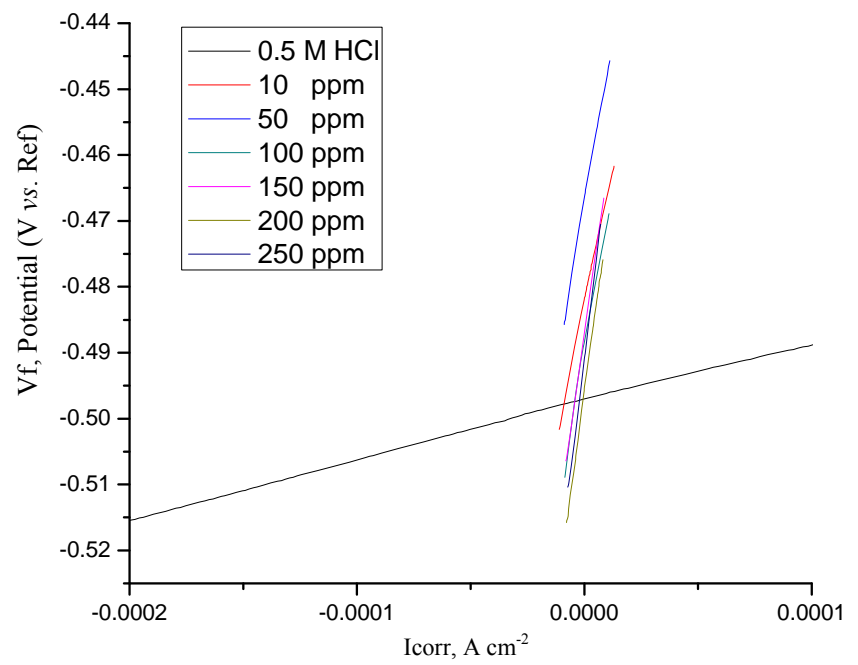

Figure 6. Linear polarization curves of carbon steel in $0.5 \mathrm{M} \mathrm{HCl}$ electrolyte alone and containing different concentrations from SAPDA at 293K

Table 5. The data were obtained by modeling LPR for carbon steel in $0.5 \mathrm{M} \mathrm{HCl}$ electrolyte solution containing different concentrations of SAPDA at 293K

\begin{tabular}{cccccccc}
\hline $\begin{array}{c}\text { Conc., } \\
\text { ppm }\end{array}$ & $\beta_{a}$ & $\beta_{c}$ & $i_{\text {corr }}$ & $-E_{\text {corr }}$ & $R_{p}$ & $C R$ & $I E$ \\
\cline { 2 - 8 } & $\mathrm{mV} \mathrm{dec}^{-1}$ & $\mathrm{mV} \mathrm{dec}^{-1}$ & $\mu \mathrm{A} \mathrm{cm}^{-2}$ & $\mathrm{mV} \mathrm{vs} \mathrm{SCE}$ & $\Omega \mathrm{cm}^{-2}$ & $\mathrm{mpy}$ & $\%$ \\
\hline 0.0 & 120 & 120 & 308.40 & 484 & 85 & 30.50 & -- \\
10 & 120 & 120 & 15.69 & 482 & 1660 & 8.86 & 94.9 \\
50 & 120 & 120 & 13.13 & 466 & 1985 & 7.41 & 95.7 \\
100 & 120 & 120 & 12.82 & 488 & 2031 & 7.24 & 95.8 \\
150 & 120 & 120 & 10.67 & 487 & 2441 & 6.02 & 96.5 \\
200 & 120 & 120 & 10.24 & 496 & 2544 & 5.78 & 96.7 \\
250 & 120 & 120 & 9.13 & 491 & 2854 & 5.15 & 97.0 \\
\hline
\end{tabular}

It's appeared that there is a shift in polarization resistance $\left(R_{p}\right)$ to higher values, with the increase in SAPDA concentration (Figure 6 and Table 5). This suggests that the corrosion inhibition of the carbon steel corrosion in the presence of SAPDA occurs by adsorption on the metal surface. 
The obtained results showed good agreement of the inhibition efficiency obtained from the potentiodynamic polarization, EIS and LPR methods as shown in Figure 7

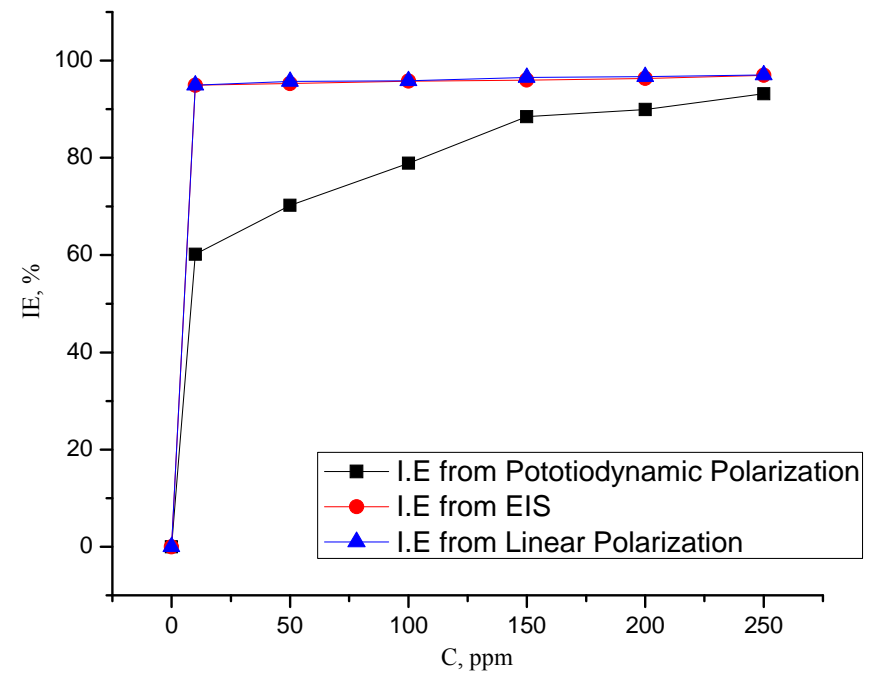

Figure 7. Comparison of inhibition obtained with the potentiometric polarization, EIS and LPR for carbon steel in $0.5 \mathrm{M} \mathrm{HCl}$ electrolyte of concentrations of 10-250 ppm of SAPDA at $293 \mathrm{~K}$

\section{Adsorption isotherms}

The available data have revealed that the action of corrosion inhibitors is due to adsorption of the inhibitor molecules on the surface of the corroding metal. The adsorption may be attributed to the nature and charge of the metallic surface, the type of the corrosive medium and the molecular structure of the inhibitor ${ }^{24,25}$.

For obtaining the best description of adsorption behavior of the inhibitor, attempts were made to fit $\theta$ values to various isotherms including Frumkin, Temkin, Freundlich and Langmuir adsorption isotherms. By far the best fit was obtained with the Langmuir isotherm and can be represented using the following equation ${ }^{26,27}$ :

$$
\frac{C_{i n h}}{\theta}=\frac{1}{K_{a d s}}-C_{i n h}
$$

Where $C_{i n h}$ is the inhibitor concentration, $K_{a d s}$ is the adsorption equilibrium constant and $\theta$ is the surface coverage.

Figure 8 shows the plots of $C_{i n h} / \theta$ against surfactant concentration $\left(C_{i n h}\right)$ at $293 \mathrm{~K}$ and the expected linear relationship is obtained with excellent correlation coefficients $\left(\mathrm{R}^{2}=\right.$ 0.9999) which confirms the validity of this approach. The slopes of the straight lines are unity, suggesting that adsorbed surfactant molecules form monolayer on the carbon steel surface and there is no interaction among the adsorbed inhibitor molecules. The large values of $K_{a d s}$ (Tables 6) obtained from the Langmuir adsorption isotherm indicate the strong adsorption of surfactant molecules on carbon steel surface. The values of the Gibbs free energy of adsorption $\left(\Delta \mathrm{G}^{\circ}\right.$ ads $)$ calculated from ${ }^{28}$ :

$$
\mathrm{K}_{\mathrm{ads}}=1 / 55.5 \exp \left(-\Delta \mathrm{G}_{\mathrm{ads}}^{\circ}\right) / \mathrm{RT}
$$


The values of $\Delta \mathrm{G}^{\circ}$ ads (Table 6) indicate that the surfactant molecules are adsorbed physically and chemically on carbon steel surface i.e. mixed one. The absolute values of $\Delta \mathrm{H}^{\circ}$ ads for adsorption are $27.4 \mathrm{~kJ} \mathrm{~mol}^{-1}$, which are lower than $40 \mathrm{~kJ} \mathrm{~mol}^{-1}$ and indicate that physisorption takes place. The $\Delta \mathrm{S}^{\circ}$ ads values are large and negative, indicating that the decrease in disordering takes place on going from the reactant to the adsorbed species $^{29}$.

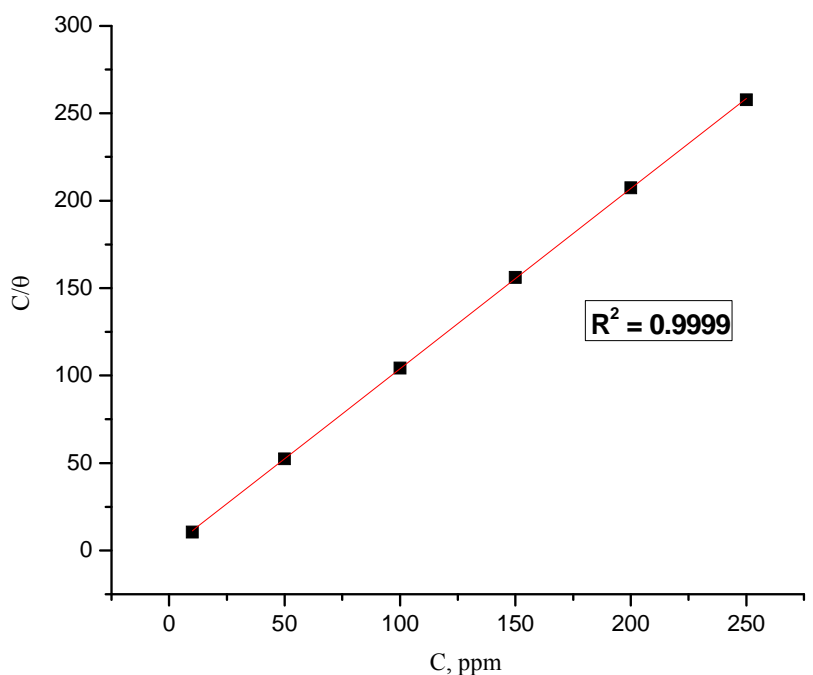

Figure 8. Linearized form of the Langmuir adsorption isotherm for adsorption of SAPDA onto the carbon steel surface at $293 \mathrm{~K}$

Table 6. Thermodynamic and equilibrium adsorption parameters for adsorption SAPDA on carbon steel surface in $0.5 \mathrm{M} \mathrm{HCl}$ solutions

\begin{tabular}{ccccc}
\hline & $\mathrm{K}_{\mathrm{ads}} \times 10^{-6} \mathrm{~L} / \mathrm{mol}$ & $\Delta \mathrm{G}_{\mathrm{ads}}^{\circ} \mathrm{kJ} \mathrm{mol}^{-1}$ & $\Delta \mathrm{H}^{\circ}{ }_{\mathrm{ads}} \mathrm{kJ} \mathrm{mol}^{-1}$ & $\Delta S^{\circ}{ }_{\text {ads }} \mathrm{J} \mathrm{mol}^{-1} \mathrm{~K}^{-1}$ \\
\hline SAPDA & 4.31 & -38.6 & 27.4 & -243.8 \\
\hline
\end{tabular}

\section{Effect of temperature}

The effect of temperature on the inhibited acid-metal reaction is very complex, because many changes occur on the metal surface such as rapid etching and desorption of inhibitor and the inhibitor itself may undergo decomposition ${ }^{26}$. To investigate the mechanism of inhibition and to calculate the activation energies of the corrosion process, potentiodynamic polarization measurements were taken at various temperatures in the absence and the presence of different concentrations of SAPDA (Figure 9). In the studied temperature range (293-323K), $i_{\text {corr }}$ values increase with increasing temperature both in uninhibited and inhibited solutions and the values of the inhibition efficiency of SAPDA decrease with increasing temperatures.

Figure 9 shows that by raising the temperature, corrosion potential shifts to nobler direction. According to the Arrhenius equation, the apparent activation energy $\left(E_{a}\right)$ of metal corrosion in both media (blank and inhibited) can be calculated from the following equations $^{30,31}$ :

$$
\log i_{\text {corr }}=\log A-\frac{E_{a}}{2.303 R T}
$$




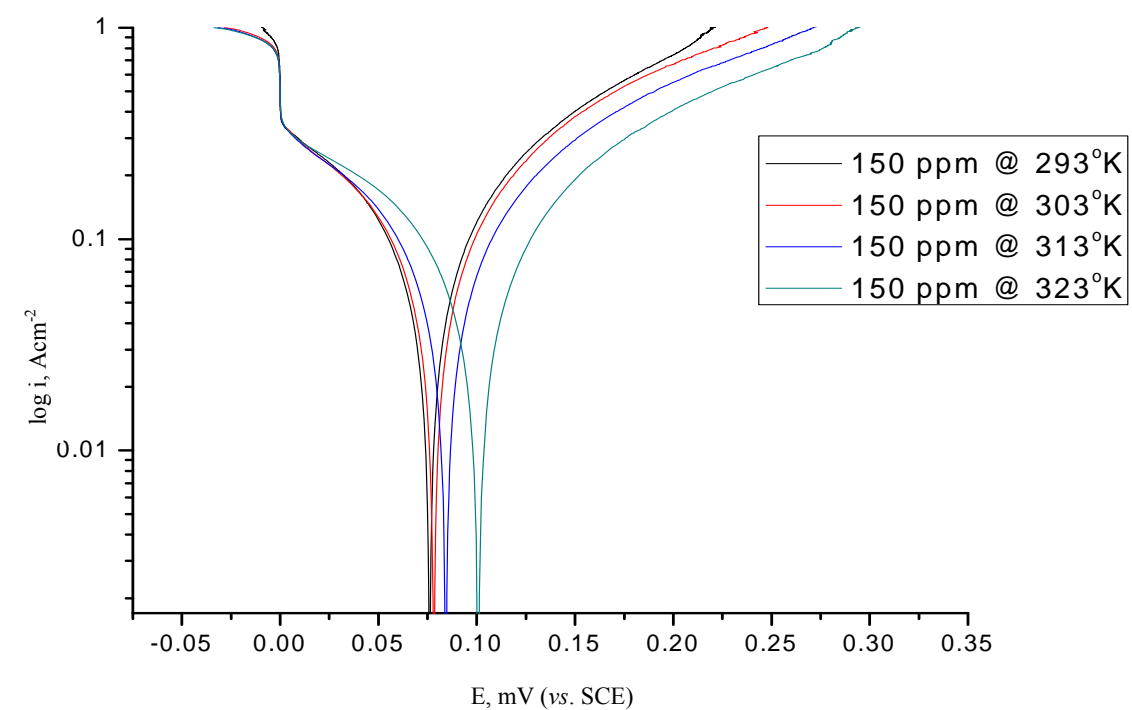

Figure 9. Tafel plot of carbon steel recorded in the presence of $150 \mathrm{ppm}$ of SAPDA in 0.5 $\mathrm{M} \mathrm{HCl}$ at $293 \mathrm{~K}, 303 \mathrm{~K}, 313 \mathrm{~K}$ and $323 \mathrm{~K}$.

Table 7. Dependence of the inhibition efficiency of SAPDA on the temperature in the absence and presence of $150 \mathrm{ppm}$ of SAPDA in $0.5 \mathrm{M} \mathrm{HCl}$ solution

\begin{tabular}{cccccccc}
\hline $\begin{array}{c}\text { Temp. } \\
\mathrm{K}\end{array}$ & $\begin{array}{c}\beta_{a} \\
\mathrm{mV} \mathrm{dec}^{-1}\end{array}$ & $\begin{array}{c}\beta_{c} \\
\mathrm{mV} \mathrm{dec}^{-1}\end{array}$ & $\begin{array}{c}i_{\text {corr }} \\
\mu \mathrm{A} \mathrm{cm}^{-2}\end{array}$ & $\begin{array}{c}-E_{\text {corr }} \\
\mathrm{mV} \mathrm{vs} \mathrm{SCE}\end{array}$ & $\begin{array}{c}C R \\
\mathrm{mpy}\end{array}$ & $\begin{array}{c}\% \\
I E\end{array}$ & $\Theta$ \\
\hline 293 & 91 & 155 & 14.4 & 501 & 8.10 & 88.5 & 0.885 \\
303 & 69 & 156 & 24.2 & 469 & 13.65 & 80.6 & 0.806 \\
313 & 77 & 163 & 34.3 & 469 & 19.36 & 72.6 & 0.726 \\
323 & 82 & 176 & 45.3 & 468 & 25.54 & 63.8 & 0.638 \\
\hline
\end{tabular}

Where $A$ is the Arrhenius pre-exponential constant. Figure 10a shows the logarithm corrosion rate $\left(i_{\text {corr }}\right)$ against the reciprocal of the absolute temperature $(1 / \mathrm{T})$ in the absence and presence of SAPDA. Straight lines are obtained. The slopes of the lines are $-E_{a} / 2.303 R$ which are extracted and shown in Table 7. The calculated value of $E_{a}$ in the absence of inhibitor is $4.6 \mathrm{~kJ} \mathrm{~mol}^{-1}$, while in the presence of SAPDA is $29.9 \mathrm{~kJ} \mathrm{~mol}^{-1}$, respectively. In the literatures, the higher $E_{a}$ for corrosion process in the presence of an inhibitor is attributed to the physisorption of inhibitor ${ }^{27,32}$.

The enthalpy and entropy of activation for the metal dissolution process are determined using the transition state Eq. (8)

$$
\log \left(\frac{i_{\text {corr }}}{T}\right)=\log \left(\frac{R}{N h}\right)+\frac{\Delta S^{*}}{2.303 R}+\frac{-\Delta H^{*}}{2.3030 R T}
$$

Where $h$ is Plank's constant and $N$ is Avogadro's number. A plot of $\log \left(\mathrm{i}_{\text {corr }} / T\right)$ versus $1 / T$ gave a straight line (Figure $10 \mathrm{~b})$ with slope $\left(-\Delta \mathrm{H}^{*} / 2.303 R\right)$ and intercept $[\log (R / N h)+$ $\left(\Delta \mathrm{S}^{*} / 2.303 R\right.$ 

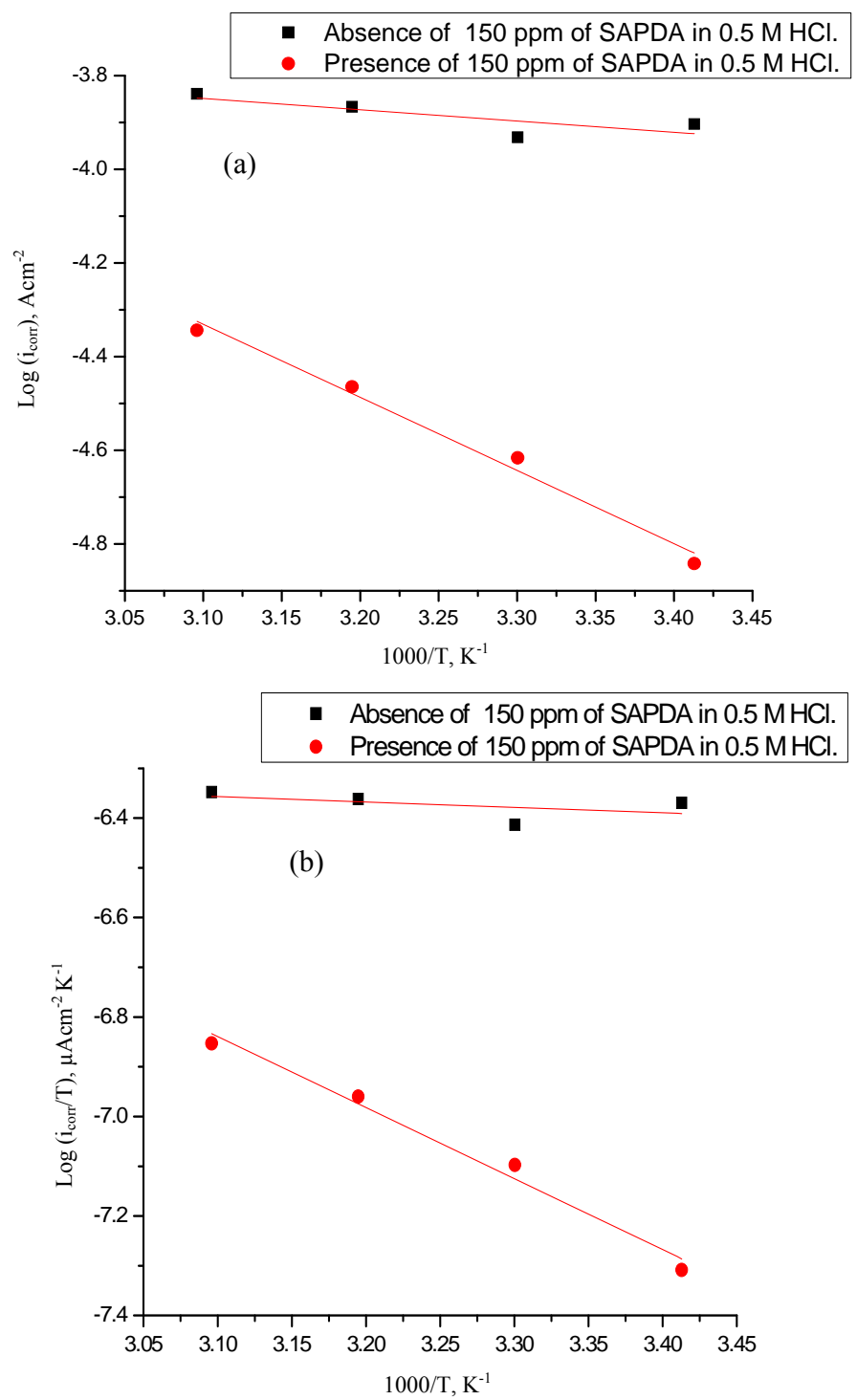

Figure 10. Arrhenius plots for carbon steel corrosion in the absence and presence of 150 ppm of SAPDA in $0.5 \mathrm{M} \mathrm{HCl}$ different temperatures (a) $\log \mathrm{i}_{\text {corr }} v s .1000 / \mathrm{T}(b) \log \mathrm{i}_{\text {corr }} / \mathrm{T} v s$. 1000/T

\section{Conclusion}

From the obtained results the following conclusions can be drown:

1 The investigated surfactant has good inhibition effect on the carbon steel in the $0.5 \mathrm{M}$ $\mathrm{HCl}$.

2 The inhibition efficiency increases by increasing surfactant concentrations and decreases by increasing the temperature.

3 The investigated surfactant acts as a mixed-type inhibitor in $0.5 \mathrm{M} \mathrm{HCl}$ 
4 Double-layer capacitance decreases and charge transfer resistance increases with respect to the blank solution when the surfactant was added

5 The apparent activation energies in the presence of the tested surfactant are smaller than that in bare $\mathrm{HCl}$ solution.

6 The adsorption of investigated surfactant on carbon steel surface obeys the Langmuir adsorption isotherm model.

\section{References}

1. Degarmo E P, Black J T and Kohser R A, Materials and Processes in Manufacturing ( $9^{\text {th }}$ Ed.), Wiley, USA, 2003.

2. Uhlig H H and Revie R W, Corrosion and Corrosion Control, Wiley, New York, 1985.

3. Alsabagh A M, Migahed M A and Hayam S A, Corros Sci., 2006, 48(4), 813-828;

DOI:10.1016/j.corsci.2005.04.009

4. Sastri V S, Corrosion Inhibitors - Principles and Applications, Wiley, Chichester, England, 1998.

5. Trabanelli G, Corrosion, 1991, 47(6), 410 - 419.

6. El Achouri M, Infante M R, Izquierdo F, Kertit S, Gouttoya H M and Nciri B, Corros Sci., 2001, 43(1), 19-35; DOI:10.1016/S0010-938X(00)00063-9

7. Aitchikh Z, Chebabe D, Dermai A, Hajjaji N, Srhiri A, Montemor M F, Ferreira M G S and Bastos A C, Corros Sci., 2005, 47(2), 447-459;DOI:10.1016/j.corsci.2004.05.028

8. Bastidas J M, Polo J L and Cano E, J Appl Electrochem., 2000, 30(10), 1173-1177; DOI:10.1023/A:1004036430497

9. Muralidharan S, Phani K L N, Pitchumani S, Ravichandran S and Iyer SV K, J Electrochem Soc., 1995, 142(5), 1478-1483; DOI:10.1149/1.2048599

10. Zhang Z, Chen S, Li Y amd Wang L, Corros Sci., 2009, 51(2), 291-300;

DOI:10.1016/j.corsci.2008.10.040

11. Hosseini S M A and Azimi A, Corros Sci., 2009, 51(4), 728- 732;

DOI:10.1016/j.corsci.2008.11.019

12. Lebrini M, Roos C, Vezin H and Robert F, Int J Electrochem Sci., 2011, 6, 3844- 3857.

13. Bentiss F, Lebrini M, Traisnel M and Lagrenee M, J Appl Electrochem., 2009, 39(8), 1399-1407; DOI:10.1007/s10800-009-9810-9

14. Tang L, Li X, Li L, Qu Q, Mu G and Liu G, Mater Chem Phys.,2005, 94(2-3), 353359; DOI:10.1016/j.matchemphys.2005.05.015

15. Bentiss F, Traisnel M and Lagrenee M, Corros Sci., 2000, 42(1), 127-146; DOI:10.1016/S0010-938X(99)00049-9

16. Bentiss F, Lebrini M, Vezin H, Chaiv, Traisnel M and Lagrenee M, Corros Sci., 2009, 51(9), 2165- 2173; DOI:10.1016/j.corsci.2009.05.049

17. Farag A A and Hegazy M A, Corros Sci., 2013, 74, 168-177; DOI:10.1016/j.corsci.2013.04.039

18. $\quad \mathrm{Li} \mathrm{W} \mathrm{H,} \mathrm{He} \mathrm{Q,} \mathrm{Pei} \mathrm{C} \mathrm{L} \mathrm{and} \mathrm{Hou} \mathrm{B} \mathrm{R,} \mathrm{Electrochim} \mathrm{Acta,} \mathrm{2007,} \mathrm{52(22),} \mathrm{6386-6397;}$ DOI:10.1016/j.electacta.2007.04.077

19. Mansfeld F, Kendig M W and Tsai S, Corrosion, 1982, 38(11), 570-580.

20. McCafferty E and Hackerman N, J Electrochem Soc., 1972, 119(2), 146-154; DOI:10.1149/1.2404150

21. McCafferty E, Introduction to corrosion science, Springer, New York, 2010.

22. Khaled K F, J Electrochim Acta, 2003, 48(97), 2493-2503; DOI:10.1016/S00134686(03)00291-3 
23. Fouda A S, El-Taib Heakal F and Radwan M S, J Appl Electrochem., 2009, 39, 391 402; DOI:10.1007/s10800-008-9684-2

24. Umoren S A, Eduok U M and Oguzie E E, J Portugal Electrochim Acta, 2008, 26(6), 533-546.

25. Zhang Q B and Hua Y X, Electrochim Acta, 2009, 54(6), 1881-1887; DOI:10.1016/j.electacta.2008.10.025

26. Bentiss F, Lebrini M and Lagrenee M, Corros Sci., 2005, 47(12), 2915-2931; DOI:10.1016/j.corsci.2005.05.034

27. Ehteram A Noor and Aisha H Al-Moubaraki, Mat Chem Phys., 2008, 110(1), 145154; DOI:10.1016/j.matchemphys.2008.01.028

28. Abd El-Lateef H M, Abbasov V M, Aliyeva L I, Qasimov E E and Ismayilov I T, Mat Chem Phys., 2013, 142(2-3), 502-512; DOI:10.1016/j.matchemphys.2013.07.044

29. Martinez S and Stern I, J Appl Surf Sci., 2002, 199(1-4), 83-89; DOI:10.1016/S01694332(02)00546-9

30. Solmaz R, Kardas G, Culha M, Yazici B and Erbil M, Electroch Acta, 2008, 53(20), 5941-5952; DOI:10.1016/j.electacta.2008.03.055

31. Hui-Long Wang, Hong-Bo Fan and Jia-Shen Zheng, J Mat Chem Phys., 2002, 77(3), 655-661; DOI:10.1016/S0254-0584(02)00123-2

32. Larabi L, Harek Y, Benali O and Ghalem S, J Prog Org Coat., 2005, 54(3), 256-262; DOI:10.1016/j.porgcoat.2005.06.015 